\title{
The Role of Parents in Online Learning at SMK 2 Respati Jakarta
}

\author{
Peran Orang Tua dalam Pembelajaran Daring di SMK 2 Respati Jakarta \\ Junita Yosephine Sinurat \\ Universitas Indraprasta PGRI \\ Jl. Raya Tengah No.80, RT.6/RW.1, Gedong, Kec. Ps. Rebo, \\ Kota Jakarta Timur, DKI Jakarta \\ junitasinurat@gmail.com
}

\begin{abstract}
Online learning is distance learning that utilizes telecommunications and information technology. Online is used as a learning model during the corona pandemic to anticipate the spread of the Covid-19. In the learning process this is less effective because there is still a lack of parental roles in mentoring, supervising and motivating children while attending school from home. Parents are the first and foremost educators in the family environment. The purpose of this study was to find out how the role of parents in online learning at SMA Respati Jakarta and what obstacles were encountered in assisting children during learning. The research used is a qualitative descriptive study. data collection was done through filling out online questionnaires via google form, and interviews. The results showed that parents play a very important role in the teaching and learning process during learning from home. Where parents act as motivators, facilitators in accompanying and teaching materials that have not been maximally delivered by teachers due to limitations during this pandemic.

Keywords: distance learning, online learning, the role of parents
\end{abstract}

\begin{abstract}
Abstrak
Pembelajaran dalam jaringan (daring) adalah pembelajaran jarak jauh yang memanfaatkan teknologi telekomunikasi dan informasi. Daring dimanfaatkan sebagai model pembelajaran selama pandemi korona sebagai antisipasi penyebaran virus Covid-19. Dalam prosesnya pembelajaran ini kurang efektif karena masih kurangnya peran orang tua dalam pendampingan, pengawasan dan memotivasi anak selama bersekolah dari rumah. Orang Tua merupakan pendidik pertama dan utama di lingkungan keluarga. Tujuan penelitian ini adalah untuk mengetahui bagaimana peran orang tua dalam pembelajaran daring di SMA Respati Jakarta dan kendala apa saja yang dihadapi dalam mendampingi anak selama pembelajaran. Metode Penelitian yang digunakan merupakan penelitian deskriptif kualitatif. pengumpulan data dilakukan melalui pengisian kuesioner online melalui Google Form, dan wawancara. Hasil penelitian menunjukkan bahwa orang tua sangat berperan dalam proses belajar mengajar selama pembelajaran dari rumah. Di mana orang tua berperan sebagai motivator, fasilitator dalam mendampingi dan mengajarkan materi yang belum maksimal disampaikan oleh guru karena keterbatasan selama pandemi ini.
\end{abstract}

Kata kunci: pembelajaran, daring, peran Orang Tua

Corresponding author: junitasinurat@gmail.com, 085297202192

\section{PENDAHULUAN}

Pandemi korona sudah berlangsung setahun lebih. Ada banyak perubahan di segala bidang sejak pandemi melanda di berbagai negara di belahan dunia. Salah satunya di bidang pendidikan yang terdampak yang sangat besar. Menteri Pendidikan dan Kebudayaan membuat kebijakan melalui surat edaran Nomor 4 tahun 2020 sebagai solusi demi menghentikan penyebaran korona maka semua siswa dan guru melaksanakan proses belajar mengajar dari rumah. Ketidaksiapan semua pihak khususnya warga sekolah menjadi suatu tantangan yang besar di mana adanya perubahan cara belajar mengajar dari tatap muka atau luring (luar jaringan) menjadi daring (dalam jaringan) yang membutuhkan kesiapan dari semua unsur, dimulai dari 
pemerintah, sekolah, guru, siswa dan orang tua. Terkait hal ini mengakibatkan pemerintah melonggarkan sistem penilaian pendidikan disesuaikan dengan keadaan darurat asalkan pembelajaran tetap dapat berlangsung tanpa harus di bebani dengan pencapaian kompetensi. Sehingga banyak para guru menggunakan daring dengan memanfaatkan teknologi yang ada.

Pembelajaran dalam jaringan (daring) adalah pembelajaran jarak jauh yang memanfaatkan teknologi telekomunikasi dan informasi. Daring dimanfaatkan sebagai model pembelajaran selama pandemi korona sebagai antisipasi penyebaran virus Covid-19. Pelaksanaan daring ini mengalami banyak kendala yang mengakibatkan tidak maksimalnya kualitas pembelajaran seperti tidak semua anak memiliki gadget/ laptop, jaringan internet yang tidak stabil, belum terbiasa dengan interaksi virtual, serta kurangnya dukungan dari orang tua.

Orang tua merupakan pendidik pertama dan utama di lingkungan keluarga. Oleh karena itu saat daring peran orang tua sebagai pendidik di rumah sangat dibutuhkan. Peran orang tua juga sangat diperlukan untuk memberikan edukasi kepada anak - anaknya yang masih belum bisa memahami tentang pandemi yang sedang mewabah untuk tetap berdiam diri di rumah agar tidak tertular dan menularkan wabah pandemi ini (Nika, 2020). Tetapi dalam prosesnya pembelajaran ini kurang efektif karena masih kurangnya peran orang tua dalam pendampingan, pengawasan dan memotivasi anak selama bersekolah dari rumah. Hal ini disebabkan banyak faktor seperti kurangnya pemahaman orang tua tentang dunia pendidikan, pekerjaan yang sibuk atau aktivitas lainnya, dan kurang sabar dalam menghadapi berbagai kesulitan ketika mendampingi anak belajar dari rumah. Berdasarkan latar belakang tersebut, peneliti tertarik untuk mengkaji lebih lanjut apa saja kendala yang dihadapi oleh orang tua siswa SMA Respati Jakarta saat mendampingi anak mereka dalam proses belajar mengajar secara daring.

Istilah "daring" merupakan akronim dari "dalam jaringan" sebagai pengganti kata online yang sering kita gunakan dalam kaitannya dengan teknologi internet. Daring adalah terjemahan dari istilah online yang bermakna tersambung ke dalam jaringan internet. Pembelajaran daring artinya adalah pembelajaran yang dilakukan secara online, menggunakan aplikasi pembelajaran maupun jejaring sosial.

Pembelajaran dalam jaringan atau disingkat dengan daring merupakan sistem pembelajaran yang dilakukan dengan tidak bertatap muka langsung, tetapi menggunakan platform yang dapat membantu proses belajar mengajar yang dilakukan meskipun jarak jauh (Sofyan dan Abdul, 2020: 28).

\section{METODE}

Metode penelitian yang digunakan dalam penelitian ini adalah penelitian deskriptif kualitatif. Menurut Sugiono (2010 : 13-14) metode penelitian kualitatif adalah metode penelitian yang berlandaskan pada filsafat postpositivisme, obyek yang alamiah, penelitinya merupakan instrumen kunci, pengambilan data sumber data secara purposive dan snowball, teknik pengumpulan data dengan trianggulasi (gabungan), analisis data bersifat induktif, dan hasil penelitian lebih bersifat makna bukan generalisasi. Sedangkan menurut Sudarman Danim (2002 :35) penelitian kualitatif tersebut mempunyai ciri-ciri: (a) fokus penelitiannya bersifat kompleks dan luas, (b) bermaksud untuk memberi makna atas fenomena secara holistik, dan (c) menempatkan diri peneliti secara aktif dalam seluruh proses penelitian.

Metode deskriptif yaitu suatu prosedur pemecahan masalah yang diselidiki dengan menggambarkan atau melukiskan suatu objek penelitian pada saat sekarang dan sebagaimana adanya. Pengambilan sampel sumber data secara purposive dan snowball, yakni sampel sumber data dipilih dengan pertimbangan tertentu (paling mengetahui apa yang kita inginkan), jumlah awalnya sedikit yang kemudian semakin banyak. Jumlah sampel tidak berdasarkan perhitungan statistic, tetapi disesuaikan untuk mendapatkan informasi yang maksimum (Sugiono, $2010: 393$ ) Sumber data dalam penelitian kualitatif dapat dibagi ke dalam tiga bagian, yakni: (1) informan; (2) dokumentasi (3) foto. Seluruh sumber data tersebut digunakan dalam penelitian ini.. Teknik

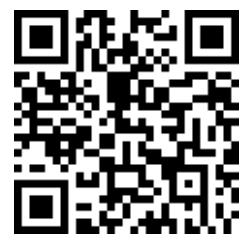

DOI PUBLIKASI https://doi.org/10.37010/int.v2i2 
pengumpulan data pada penelitian ini dilakukan melalui: (1) pengamatan (observasi) dan wawancara.

\section{HASIL DAN PEMBAHASAN}

Pandemi Covid-19 sudah melanda Negara Indonesia sejak Maret 2020, yang berdampak luar biasa pada berbagai bidang. Sesuatu yang serba mendadak, dan mau tidak mau masyarakat harus beradaptasi dengan berbagai perubahan secara cepat. Salah satu bidang yang mengalami dampak yaitu bidang pendidikan. Untuk mengantisipasi penyebaran virus korona, Pemerintah membuat kebijakan agar kegiatan belajar mengajar dilaksanakan dari rumah dalam bentuk pembelajaran dalam jaringan (daring).

Dengan adanya tuntutan yang mewajibkan untuk belajar maka melaksanakan pembelajaran di rumah atau pembelajaran jarak jauh (PJJ) sebagai pengganti dari kegiatan belajar mengajar yang dilakukan di sekolah. Meskipun pada awalnya banyak orang tua yang menolak pembelajaran jarak jauh untuk anaknya dengan berbagai alasan seperti kesulitan mendampingi anak belajar, dana untuk kuota belajar yang cukup mahal serta perlunya dana untuk memfasilitasi anak untuk memiliki gadget atau laptop yang digunakan sebagai media belajar. Namun seiring berjalannya waktu, orang tua mulai menerima pembelajaran jarak jauh ini. Terlebih adanya Surat Edaran no. 4 tahun 2020 dari Menteri Pendidikan dan Kebudayaan yang menganjurkan seluruh kegiatan di institusi pendidikan harus jaga jarak dan seluruh penyampaian materi akan disampaikan di rumah masing-masing.

Demi kebaikan bersama dalam rangka memutus mata rantai penyebaran covid-19 maka selama satu setengah tahun pembelajaran jarak jauh ini sudah dilaksanakan dengan adanya berbagai kelebihan dan kekurangan dalam setiap prosesnya. Kelebihannya adalah para guru-guru menjadi lebih kreatif, inovatif dan melek teknologi karena adanya tuntutan mengetahui dan menguasai teknologi pembelajaran yang dimanfaatkan sebagai media pembelajaran daring. Kekurangannya bagi pendidik adalah para guru tidak bisa memantau secara langsung bagaimana kondisi peserta didik saat proses belajar mengajar berlangsung. Sedangkan bagi peserta didik kelemahannya adalah ternyata pembelajaran daring belumlah dirasa efektif dan maksimal.

Berdasarkan hasil survei UNICEF juga menerima tanggapan lebih dari 4000 siswa di 34 provinsi di Indonesia yang diselenggarakan bulan Mei-Juni 2020 yang lalu terkait dengan pengalam belajar siswa dari rumah selama pandemi Covid-19 disebutkan sebanyak 66 persen dari 60 juta siswa dari berbagai jenjang pendidikan di 34 provinsi mengaku tidak nyaman belajar di rumah selama pandemi Covid-19. Dai jumlah tersebut, 87 persen siswa ingin segera kembali belajar di sekolah.

Meski begitu, siswa telah menyadari dampak Covid-19 bila mereka kembali ke sekolah, sehingga menurut mereka akan lebih baik untuk menunggu sampai jumlah kasus Covid-19 berkurang. Pemerintah sudah menanggapi berbagai keluhan dari tenaga pendidik, orang tua siswa, dan siswa/i di seluruh Indonesia dengan membuat kebijakan baru yaitu kembali ke sekolah dengan program tatap muka terbatas. Tetapi hal tersebut belumlah dapat direalisasikan karena semakin meningkatnya kasus Covid-19 di Indonesia.

Kualitas belajar peserta didik yang semakin menurun dari hari ke hari selama pembelajaran jarak jauh membutuhkan penanganan lebih lanjut yaitu guru perlu melakukan motivasi dan bimbingan juga peran serta orang tua sebagai sosok guru di rumah. Peran orang tua di sini diharapkan siap selalu untuk mendukung, memotivasi, dan mengajar serta mencari solusi apabila pembelajaran mengalami hambatan agar pembelajaran yang optimal dapat tercapai.

Pembelajaran jarak jauh diterapkan dengan memanfaatkan beberapa platform untuk tatap muka seperti Zoom Meet, Google Meet. Pembelajaran daring dapat memanfaatkan learning management system (LMS), rumah sekolah serta pemanfaatan media sosial seperti WhatsApp Grup, YouTube, Facebook dan Instagram. Salah satu platform tersebut dipilih guru dengan 
menyesuaikan materi dan kondisi peserta didik. Setiap media yang digunakan memiliki kelebihan dan kekurangan masing-masing, sehingga guru perlu lebih bijak dalam mempertimbangkannya.

Pada kenyataannya, kesulitan-kesulitan dalam proses pembelajaran membuat orang tua kewalahan sehingga banyak orang tua hampir menyerah dengan pembelajaran daring. Beberapa orang tua juga mengalami kendala terkait masalah waktu, di mana mereka tidak mampu meluangkan waktu berpartisipasi mendampingi anak dalam proses pembelajaran daring (Winarti dalam Nurhasanah, 2020:63). Begitu juga dengan model pembelajaran yang diterapkan secara tiba-tiba tanpa adanya pembekalan membuat seluruh warga sekolah dan orang tua siswa harus beradaptasi secara cepat. Bila ditemukan kekurangan-kekurangan sebenarnya ini adalah hal yang wajar dan harus segera dievaluasi. Hal ini seperti apa yang dikatakan oleh Bu Aminah dan Bu Widya dalam wawancara yang dilakukan tanggal 30 Juli 2021 yaitu mereka mengeluhkan anaknya yang semakin hari semakin malas belajar.

Saya terkadang sampai teriak untuk menyuruh anak belajar, saban hari hanya main HP. Sekarang ini sulit membedakan anak sedang belajar atau tidak, karena sering kali main HP dari bangun tidur sampai mau tidur kembali dengan alasan sekolah daring tetapi saat dicek yang dibuka hanya TikTok, Instagram, main game. Kata gurunya juga anak saya sering tidak mengirimkan tugas. Saya pikir selama anak belajar dari rumah, pekerjaan di rumah akan semakin mudah karena anak bisa bantu untuk ikut mengerjakan pekerjaan rumah tetapi yang ada saya malah sampai stres menghadapi anak sepanjang hari.

Mengingat pentingnya peran orang tua dalam mendampingi proses belajar anak, jadi orang tua dapat disebut juga sebagai garda terdepan dalam menentukan prestasi belajar anak. Orang tua yang fokus dan penuh perhatian akan berdampak pada peningkatan prestasi anak, karena anak akan semakin termotivasi dan giat belajar karena adanya guru di rumah yang siap mendampingi. Peran tersebut bukan harus duduk di samping anak selama pembelajaran karena hal tersebut mungkin saja tidak bisa dilakukan oleh orang tua yang masih tetap harus bekerja di luar rumah selama pandemi korona ini.

Dalam mendampingi anak, setiap orang tua tentunya memiliki metode yang berbedabeda satu sama lainnya. Hal ini bisa dipengaruhi latar belakang pendidikan, pengalaman, bakat, maupun latar belakang lainnya yang bisa dipelajari secara langsung maupun tidak langsung.

Peran orang tua sebagai motivator dapat dilakukan dengan cara memberi motivasi anak agar tetap semangat dan giat dalam pembelajaran daring, memberi reward ketika anak mendapatkan hasil yang baik dalam belajar, dan memberi nasihat kepada anak ketika semangat belajar anak turun. Orang tua sebagai fasilitator dapat melakukan upaya dengan menyediakan fasilitas pembelajaran di rumah yang memadai kepada anaknya dengan maksimal. Terkait dengan fasilitas pembelajaran, berdasarkan hasil wawancara dengan narasumber, mereka juga mengeluhkan kesulitan untuk melengkapi kebutuhan anak di tengah kesulitan ekonomi. Apalagi sebagian besar anak-anak ini berasal dari keluarga menengah ke bawah, dan banyak yang merupakan pekerja harian. Pemberlakuan kebijakan seperti PSBB, PPKM sangat berdampak pada perekonomian mereka. Apabila mereka tidak bekerja maka tidak ada uang yang bisa dibawa ke rumah. Ibu Nia salah satu orang tua siswa baru saja dirumahkan, di mana sebelumnya bekerja di sebuah salon di sebuah mal. Dia menyebutkan bahwa untuk memenuhi kebutuhan sehari-hari saja sudah sangat sulit apalagi untuk membiayai kuota internet untuk 3 anaknya dan melengkapi fasilitas belajar lainnya seperti HP dan laptop. Anak-anaknya harus bergantian menggunakan laptop karena memang dia hanya sanggup membelikan 1 laptop yang lebih sering digunakan anaknya yang sulung yaitu Dita, siswa kelas XI SMK Respati.

Oleh karena itu di tengah berbagai kesulitan seperti ekonomi, kondisi belajar yang kurang nyaman, materi pembelajaran yang sulit dipahami, kondisi mental anak selama proses belajar mengajar maka orang tua diharapkan mampu berperan optimal sebagai guru dan sahabat anak juga sebagai motivator dan fasilitator.

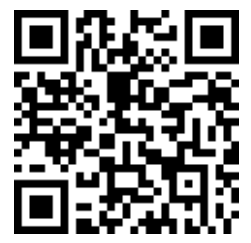

DOI PUBLIKASI https://doi.org/10.37010/int.v2i2 


\section{PENUTUP}

Berdasarkan hasil dan pembahasan di atas, maka peneliti menyimpulkan bahwa:

1. Kualitas belajar peserta didik semakin menurun dari hari ke hari selama pembelajaran jarak jauh sehingga membutuhkan penanganan lebih lanjut baik oleh guru maupun orang tua.

2. Setiap orang tua memiliki metode pendampingan anak yang berbeda-beda satu sama lainnya. Hal ini bisa dipengaruhi latar belakang pendidikan, pengalaman, bakat, maupun latar belakang lainnya yang bisa dipelajari secara langsung maupun tidak langsung.

3. Peran orang tua sebagai motivator dapat dilakukan dengan cara memotivasi anak agar tetap semangat dan giat dalam pembelajaran daring, memberi reward ketika anak mendapatkan hasil yang baik dalam belajar, dan memberi nasihat kepada anak ketika semangat belajar anak turun. Orang tua sebagai fasilitator dapat melakukan upaya dengan menyediakan fasilitas pembelajaran di rumah yang memadai kepada anak.

\section{DAFTAR PUSTAKA}

Danim, S. (2002). Menjadi Peneliti Kualitatif, Bandung: Pustaka Setia.

Lincoln, Y. \& Egon G. G. (1985). Naturalitic Inquiry. (London: Sage Publication).

Menteri Pendidikan dan Kebudayaan Republik Indonesia. (2020). Surat Edaran Nomor 4 Tahun 2020 Tentang Pelaksanaan Kebijakan Pendidikan Dalam Masa Darurat Penyebaran Coronavirus Disease (COVID-19).

Nika, C. \& Rita, K. (2020). Peran Orang Tua Dalam Menerapkan Pembelajaran

Di Rumah Saat Pandemi Covid 19. Jurnal Golden Age, 4(1).

Nurhasanah, R. (2020). Peran Orantua Dalam Pembelajaran Daring di Masa Pandemi Covid 19 Pada Kelompok B5 TK Kemala Bhayangkari Bone. Jurnal Educhild, 2(2).

Sofyan dan Abdul. (2020). Pembelajaran Daring Kombinasi Berbasis Whatsapp Pada Kelas

Karyawan Prodi Teknik Informatika Universitas PGRI Madiun. Jurnal Nasional Pendidikan Teknik Informatika. 8(1).

Sucipto dan Raflis. (2000). Profesi Keorangtuaan. Jakarta: RI

Sugiono. (2010). Metode Penelitian Bisnis. Bandung: Alfa Beta. 